\title{
Financial Technology Peer-To-Peer Lending Berbasis Syariah di Indonesia
}

\author{
Jadzil Baihaqi \\ Institut Agama Islam Negeri Kudus \\ jadzilbaihaqi@iainkudus.ac.id
}

\begin{abstract}
This research aims to explain the concept of online peer-to-peer lending based on sharia rules. This research uses a literature study. The findings are, first, online peer-to-peer lending allowed in Islamic law that free from prohibited transactions, using sharia contracts, transparent, and in good manner. Second, there are 6 online peer-to-peer lending models that can be done according to Fatwa DSN-MUI: 1) financing for factoring, 2) financing for procurement ordered good, 3) financing for online seller, 4) financing for online seller through payment gateway, 5) financing for employee, 5) financing for community-based.
\end{abstract}

Keywords: Financial technology peer-to-peer lending, DSN-MUI, Sharia

\begin{abstract}
Abstrak
Penelitian ini bertujuan untuk menjelaskan konsep Financial Technology Peer-to-peer Lending yang dijalankan dengan prinsip syariah. Penelitian ini menggunakan metode studi literatur yang membahas atau mencari referensi teori serta referensi yang relevan dengan topik yang diangkat. Peneliti menemukan bahwa pada dasarnya Fintech Peer-to-peer Lending secara syariat Islam boleh dilakukan dengan syarat mengikuti prinsip-prinsip Syariah. Prinsip Syariah yang dimaksud adalah terbebas dari transaksi yang dilarang, menggunakan akad Syariah, transparan, dan dilakukan dengan sikap yang baik. Fintech peer-to-peer lending berdasarkan prinsip Syariah menurut Fatwa DSN-MUI dapat dilakukan dengan model: 1) pembiayaan anjak piutang, 2) pembiayaan pengadaan barang pesanan pihak ketiga, 3) pembiayaan pengadaan barang untuk pelaku usaha yang berjualan secara online, 4) pembiayaan pengadaan barang untuk pelaku usaha yang berjualan secara online dengan pembayaran melalui payment gateway, 5) pembiayaan untuk pegawai, 6) pembiayaan berbasis komunitas.
\end{abstract}

Kata Kunci: Financial technology peer-to-peer lending, DSN-MUI, Syariah

\section{PENDAHULUAN}

Revolusi industri 4.0 yang ditandai dengan kemajuan teknologi membawa perubahan dalam kehidupan masyarakat secara signifikan. Perubahan tersebut terjadi hampir di semua lini, bidang sosial, ekonomi, komunikasi, pendidikan, dan lainnya. Kemajuan teknologi ini bisa mempengaruhi kehidupan secara positif maupun negatif. Misalnya dalam hal ekonomi, munculnya ojek online, bagi seorang yang berprofesi sebagai tukang ojek pengkolan akan membawa dampak negatif bagi kehidupannya karena dapat mematikan usahanya. Namun, jika tukang ojek pengkolan 
dapat menerima dan memanfaatkan kesempatan tersebut, maka peluang mendapatkan penghasilan yang lebih besar juga semakin tinggi.

Jasa pemberian layanan keuangan juga mengalami evolusi. Muncul inovasi-inovasi baru di bidang pendanaan dan pembiayaan. Banyak bermunculan jasa-jasa keuangan non-bank yang kemudian disebut Industri Keuangan Non-Bank yang berisi jasa keuangan selain perbankan dan pasar modal seperti asuransi, dana pensiun, Lembaga pembiayaan, dan Lembaga keuangan mikro. Dalam periode tahun 2010 s.d. 2014, sektor keuangan Syariah di Indonesia termasuk IKNB tumbuh signifikan. IKNB Syariah telah mengalami pertumbuhan rata-rata 62,29\% per tahun (OJK, 2015). Namun di sisi yang lain, market share IKNB Syariah terhadap total aset IKNB hanya sebesar $4 \%$. Hal ini menjadi peluang dan tantangan yang cukup berat bagi pihak-pihak yang berkepentingan untuk mengembangan IKNB Syariah.

Pada industri pembiayaan Syariah, kehadirannya sangat diperlukan oleh usaha mikro, kecil, dan menengah (UMKM). Berdasarkan data Kementerian Koperasi dan Usaha Kecil dan Menengah, pada tahun 2015 jumlah UMKM di Indonesia sebanyak 59,2 juta unit (Kementerian Koperasi dan UKM, 2017). Dengan jumlah yang sangat besar tersebut, potensi penyaluran pembiayaan Syariah sangat tinggi. Penyaluran pembiayaan Syariah tidak semuanya dapat dilakukan oleh perbankan Syariah dikarenakan adanya persyaratan yang tidak mampu dipenuhi oleh UMKM. Oleh karena itu, diperlukan Lembaga pembiayaan yang mampu memenuhi kebutuhan UMKM dan masyarakat secara umum.

Dalam satu dekade terakhir di dunia sedang berkembang model bisnis baru, yaitu online peer-to-peer lending. Model bisnis ini merupakan salah satu inovasi yang penting dalam bisnis pembiayaan khusunya pada era keuangan digital seperti saat ini (Cai, Lin, Xu, \& Fu, 2016). Peer-to-peer lending merupakan platform baru transaksi keuangan yang menyederhanakan fungsi intermediasi konvensional dengan secara langsung mempertemukan pihak yang membutuhkan dana dengan pihak yang kelebihan dana (Yum, Lee, \& Chae, 2012).

Di Indonesia, perusahaan online peer-to-peer lending mulai muncul secara legal pada tahun 2017 (OJK, 2018). Berdasarkan data Direktori Fintech OJK Sampai dengan bulan Juni 2018, sudah terdaftar 64 perusahaan fintech peer-to-peer lending yang beroperasi secara legal di Indonesia. Sedangkan yang belum mendaftar ke OJK juga tidak sedikit. Hal ini menunjukkan bahwa model bisnis pembiayaan ini sangat potensial dan memiliki prospek pertumbuhan yang bagus. Dari 64 perusahaan fintech tersebut, hanya dua perusahaan yang bergerak dengan prinsip Syariah. Padahal peluang penyaluran pembiayaan Syariah sangat tinggi. Hal ini diidentifikasi oleh OJK dikarenakan kurang pahamnya masyarakat 
terhadap produk keuangan Syariah. Dengan kata lain, peluang penyaluran pembiayaan Syariah harus didukung oleh literasi masyarakat terhadap produk pembiayaan itu sendiri.

Oleh karena itu, tujuan dari penelitian ini adalah untuk menjelaskan bagaimana mekanisme dan model fintech peer-to-peer lending berlandaskan prinsip Syariah di Indonesia berdasarkan Fatwa DSN-MUI. Penelitian ini juga bertujuan untuk berkontribusi dalam literatur tentang fintech peer-topeer lending yang diperbolehkan menurut syariat Islam.

\section{METODE PENELITIAN}

Kajian ini mencakup studi literatur yang membahas atau mencari referensi teori serta referensi yang relevan dengan topik yang diangkat. Desain studi literatur adalah serangkaian kegiatan yang berkenaan dengan metode pengumpulan data pustaka, membaca dan mencatat, serta mengelolah bahan penelitian (Creswell, 2010). Teori dan referensi itu sendiri diperoleh dengan melakukan kajian studi pustaka yang menjadi pondasi dasar atau instrumen utama untuk praktik risetnya. Studi pustaka dilakukan dengan mengumpulkan berbagai sumber sebagai topik baru yang diangkat dalam penelitian. Semua data yang telah dikumpulkan kemudian dianalisis dengan menggunakan metode analisis deskriptif, yaitu dengan menggambarkan fakta-fakta yang diikuti dengan analisis yang tidak hanya menggambarkan, tetapi juga memberikan pemahaman dan penjelasan yang memadai.

\section{PEMBAHASAN}

\section{Theory of Consumer Choice and Demand}

Teori ekonomi ini intinya ada pada pilihan konsumen (Au \& Kauffman, 2008). Konsumen dapat memilih sesuai dengan keinginannya berdasarkan pilihan alternatif yang paling menguntungkan. Di era digitalisasi ini, teknologi begitu memanjakan pemakainya termasuk di bidang keuangan dan pembiayaan. Konsumen akan memilih berdasarkan kepuasan atau kenyamanan layanan, kemudahan penggunaan dan akses, serta manfaat yang diperoleh. Hal ini selaras dengan hasil penelitian Davis (1989) tentang perilaku pengguna (user behavior) dan penerimaan pengguna (user acceptance) terhadap teknologi informasi berdasarkan kegunaan (usefulness) dan kemudahan pemakaian (ease of use) yang terkenal dengan technology acceptance model (TAM).

Theory of consumer choice and demand dapat digunakan untuk menjelaskan bahwa layanan pembiayaan digital seperti fintech peer-to-peer lending ini memiliki potensi untuk berkembang dengan pesat karena masyarakat diberikan fasilitas kemudahan dalam mendapatkan 
pembiayaan maupun berinvestasi. Dengan ditambah semangat ta'awun (tolong-menolong) sebagai sesama manusia, tidak hanya sebatas mendapatkan keuntungan, maka para pengguna fintech peer-to-peer lending dapat secara mudah bekerjasama dalam menjalankan sebuah usaha.

\section{Konsep Financial Technology Peer-to-peer Lending}

Peraturan Otoritas Jasa Keuangan Nomor 77/POJK.01/2016 tentang layanan pinjam meminjam uang berbasis teknologi informasi menjelaskan bahwa layanan pinjam meminjam uang berbasis teknologi informasi adalah penyelenggara layanan jasa keuangan untuk mempertemukan pemberi pinjaman dengen penerima pinjaman dalam rangka melakukan perjanjian pinjam meminjam dalam mata uang rupiah secara langsung melalui sistem elektronik dengan menggunakan jaringan internet.

Dalam peraturan OJK tersebut diatur para pengguna jasa layanan fintech peer-to-peer lending yaitu penerima pinjaman dan pemberi pinjaman. Penerima pinjaman harus warga negara Indonesia atau badan hukum Indonesia. Sedangkan pemberi pinjaman dapat berasal dari dalam dan luar negeri. Perjanjian yang dilakukan ada dua, yaitu perjanjian antara penyelenggara dengan pemberi pinjaman, dan perjanjian antara pemberi pinjaman dengan penerima pinjaman. Perjanjian ini harus dituangkan dalam dokumen elektronik yang isinya menjamin kejelasan transaksi dan akses informasi kepada pemberi pinjaman maupun penerima pinjaman. Dokumen elektronik perjanjian dilaksanakan dengan menggunakan tanda tangan elektronik yang mengikuti ketentuan peraturan perundangundangan yang mengatur.

Untuk menjamin keamanan para pengguna, penyelenggara dapat bekerjasama dan melakukan pertukaran data dengan penyelenggara layanan pendukung berbasis teknologi informasi seperti bank. Selain itu, penyelenggara diwajibkan menggunakan escrow account (untuk penyelenggara) dan virtual account (untuk pemberi pinjaman).

Peraturan Bank Indonesia Nomor 19/12/PBI/2017 tentang penyelenggaraan teknologi finansial menegaskan pengertian teknologi finansial (financial technology) sebagai penggunaan teknologi dalam sistem keuangan yang menghasilkan produk, layanan, teknologi, dan/atau model bisnis baru serta dapat berdampak pada stabilitas moneter, sistem keuangan, dan/atau efisiensi, kelancaran, keamanan, dan keandalan sistem pembayaran. Teknologi finansial (fintech) yang dimaksudkan adalah yang termasuk dalam sistem pembayaran, pendukung pasar, manajemen investasi dan manajemen risiko, pinjaman, pembiayaan, penyediaan modal, dan jasa finansial lainnya.

Fintech peer-to-peer lending tergolong aktivitas pembaruan proses bisnis, model bisnis, dan instrument keuangan yang memberikan nilai 
tambah baru di sektor jasa keuangan dengan melibatkan ekosistem digital yang dikenal dengan istilah inovasi keuangan digital (IKD).

Fintech peer-to-peer lending merupakan alternatif potensial sumber pembiayaan bagi masyarakat terutama untuk pembiayaan bagi usaha mikro, kecil, dan menengah (UMKM). Dalam pelaksanaan operasionalnya, sistem dalam fintech peer-to-peer lending sangat mudah untuk diakses, baik oleh pemberi pembiayaan maupun penerima pembiayaan. Hal ini menimbulkan risiko tersendiri dari mudahnya sistem tersebut. Untuk melindungi kepentingan konsumen terkait keamanan dana serta menjaga stabilitas sistem keuangan, maka pemberian pembiayaan tersebut dibatasi total maksimum sebesar Rp 2.000.000.000 (dua miliar rupiah).

Fintech peer-to-peer lending berdasarkan prinsip Syariah merupakan penyelenggaraan layana jasa keuangan berdasarkan prinsip Syariah yang mempertemukan atau menghubungkan pemberi pembiayaan dengan penerima pembiayaan dalam rangka melakukan akad pembiayaan melalui sistem elektronik dengan menggunakan jaringan internet. Konsep fintech peer-to-peer lending berdasarkan prinsip Syariah merupakan konsep penyelenggaraan layanan pembiayaan berbasis teknologi dengan tujuan untuk menghindari praktik yang dilarang oleh hukum Islam. Hal ini memberikan media bagi para pelaku kegiatan pembiayaan melalui penyelenggara fintech untuk melaksanaan transaksi berdasarkan prinsip Syariah yang diperbolehkan oleh hukum Islam.

\section{Ketentuan Hukum Fintech peer-to-peer lending}

Fintech peer-to-peer lending menurut Fatwa Dewan Syariah NasionalMajelis Ulama Indonesia Nomor 117/DSN-MUI/II/2018 dibolehkan dengan syarat sesuai dengan prinsip Syariah. Ketentuan prinsip Syariah yang dimaksud adalah 1) terhindar dari riba, gharar (ketidakpastian), maysir (spekulasi), tadlis (menyembunyikan cacat), dharar (merugikan pihak lain), dan haram; 2) Akad baku memenuhi prinsip keseimbangan, keadilan, dan kewajaran sesuai Syariah dan peraturan perundang-undangan yang berlaku; 3) Akad yang digunakan selaras dengan karakteristik layanan pembiayaan seperti al-bai', ijarah, mudharabah, musyarakah, wakalah bi al ujrah, dan qardh; 4) Terdapat bukti transaksi yaitu berupa sertifikat elektronik dan harus divalidasi oleh pengguna melalui tanda tangan elektronik yang sah;

5) Transaksi harus menjelaskan ketentuan bagi hasil yang sesuai dengan Syariah; 6) penyelenggara layanan boleh mengenakan biaya (ujrah) dengan prinsip ijarah.

Subyek hukum dalam fintech peer-to-peer lending ada tiga pihak, yaitu penyelenggara, penerima pembiayaan, dan pemberi pembiayaan. 


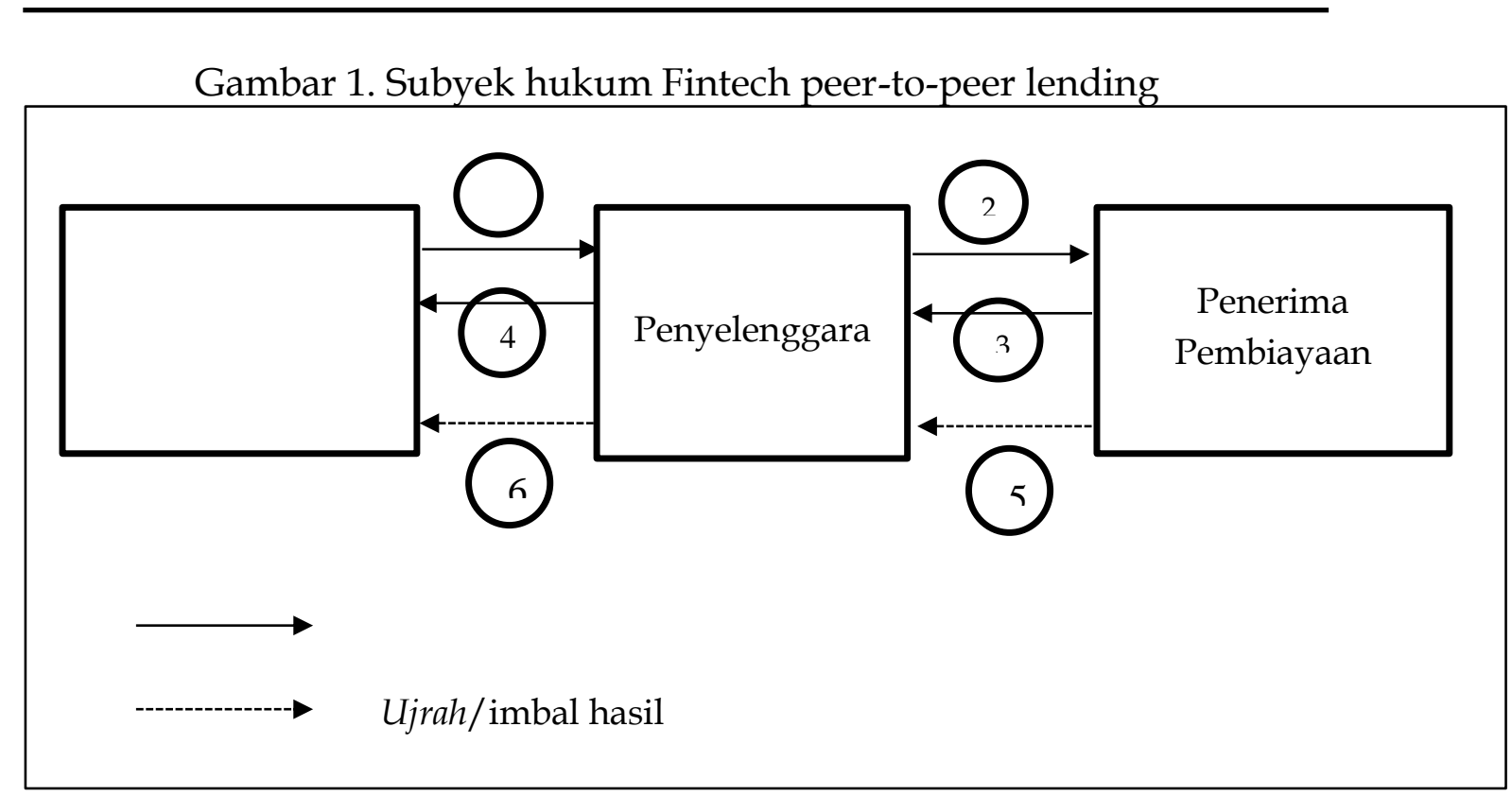

Keterangan:

1. Pemberi pembiayaan menyalurkan dana melalui penyelenggara

2. Penyelenggara menyalurkan dana ke penerima pembiayaan

3. Penerima pembiayaan mengembalikan dana melalui penyelenggara

4. Penyelenggara mengembalikan dana kepada pemberi pembiayaan

5. Pemberi pembiayaan membayar ujrah/imbal hasil kepada penyelenggara

6. Penyelenggara memberikan ujrah/imbal hasil kepada pemberi pembiayaan

\section{Model dan Mekanisme Fintech Peer-to-peer Lending Berbasis Syariah}

Financial technology peer-to-peer lending merupakan salah satu bentuk inovasi teknologi di bidang layanan jasa keuangan khususnya pinjaman/pembiayaan/pendanaan yang menghilangkan hambatanhambatan yang sering dialami masyarakat. Saat ini dengan hadirnya fintech ini masyarakat dapat dengan mudah mengakses pinjaman/pembiayaan untuk mengingkatkan usaha yang dimiliki atau kebutuhan rumah tangga yang harus segera dipenuhi.

Fintech peer-to-peer lending berdasarkan prinsip Syariah menurut Fatwa DSN-MUI dapat dilakukan dengan model: 1) pembiayaan anjak piutang, 2) pembiayaan pengadaan barang pesanan pihak ketiga, 3) pembiayaan pengadaan barang untuk pelaku usaha yang berjualan secara online, 4) pembiayaan pengadaan barang untuk pelaku usaha yang berjualan secara online dengan pembayaran melalui payment gateway, 5) pembiayaan untuk pegawai, 6) pembiayaan berbasis komunitas. 


\section{1) Pembiayaan anjak piutang (factoring)}

Anjak piutang syariah sudah diatur sendiri dalam Fatwa DSN-MUI Nomor 67/DSN-MUI/III/2008. Adapun ketentuan dalam fatwa tersebut adalah: 1) akad yang digunakan adalah wakalah bi al-ujrah; 2) Pihak yang berpiutang mewakilkan kepada pihak lain untuk melakukan pengurusan dokumen penjualan kemudian menagihkan piutang kepada pihak yang berutang; 3) pihak yang ditunjuk menjadi wakil dari yang memiliki piutang untuk melakukan penagihan kepada pihak yang berutang atau pihak lain yang ditunjuk oleh pihak yang berutang untuk membayar; 4) Pihak yang ditunjuk menjadi wakil dapat memberikan dana talangan (qardh) kepada pihak yang memiliki piutang sebesar nilai piutang; 5) atas jasanya melakukan penagihan, pihak yang ditunjuk menjadi wakil dapat memperoleh ujrah/fee; 6) Besar ujrah/fee harus disepakati pada saat akad dan dinyatakan dalam bentuk nominal, bukan dalam bentuk prosentase yang dihitung dari pokok piutang; 7) pembayaran ujrah dapat diambil dari dana talangan atau sesuia kesepakatan dalam akad; 8) antara akad wakalah bi al-ujrah dan akad qardh tidak dibolehkan adanya keterkaitan (ta'alluq).

Model pembiayaan anjak piutang dilakukan dengan memberikan pembiayaan dalam bentuk jasa pengurusan penagihan piutang berdasarkan bukti tagihan (invoice), baik disertai maupun tidak disertai talangan ( qardh) yang diberikan kepada pelaku usaha yang memiliki tagihan kepada pihak ketiga (payor). Mekanismenya adalah:

a) Adanya akad yang menimbulkan hubungan hukum utang piutang yang ditunjukkan dengan bukti tagihan (invoice) oleh pelaku usaha yang memiliki tagihan kepada pihak ketiga (payor) yang menjadi dasar jasa dan/atau pembiayaan anjak piutang.

b) Pelaku usaha atas dasar bukti tagihan yang dimiliki mengajukan jasa dan/atau pembiayaan kepada penyelenggara.

c) Penyelenggara menawarkan kepada calon pemberi pembiayaan untuk memberikan jasa penagihan piutang berdasarkan invoice baik disertai talangan (qardh) atau tidak.

d) Jika ada calon pemberi jasa dan/atau pembiayaan menyetujui penawaran, dilakukanlah akad antara pemberi pembiayaan dengan penyelenggara. Akad yang digunakan adalah akad wakalah bi alujrah, pemberi pembiayaan sebagai muwakkil dan penyelenggara sebagai wakil.

e) Kemudian penyelenggara melakukan akad wakalah bi al-ujrah dengen penerima pembiayaan untuk penagihan utang. Penyelenggara sebagai wakil, dan penerima pembiayaan sebagai muwakkil. 
f) Penyelenggara sebagai wakil dari pemberi pembiayaan dapat memberikan talangan dana dengan akad qardh kepada penerima pembiayaan/jasa.

g) Penyelenggara melakukan penagihan kepada pihak ketiga (payor) atas piutang penerima pembiayaan.

h) Penerima pembiayaan membayar ujrah kepada penyelenggara.

i) Penerima pembiayaan membayar utang qardh (jika ada) kepada penyelenggara sebagai wakil.

j) Penyelenggara wajib menyerahkan ujrah dan qardh (jika ada) kepada pemberi pembiayaan.

Gambar 2. Mekanisme model pembiayaan anjak piutang

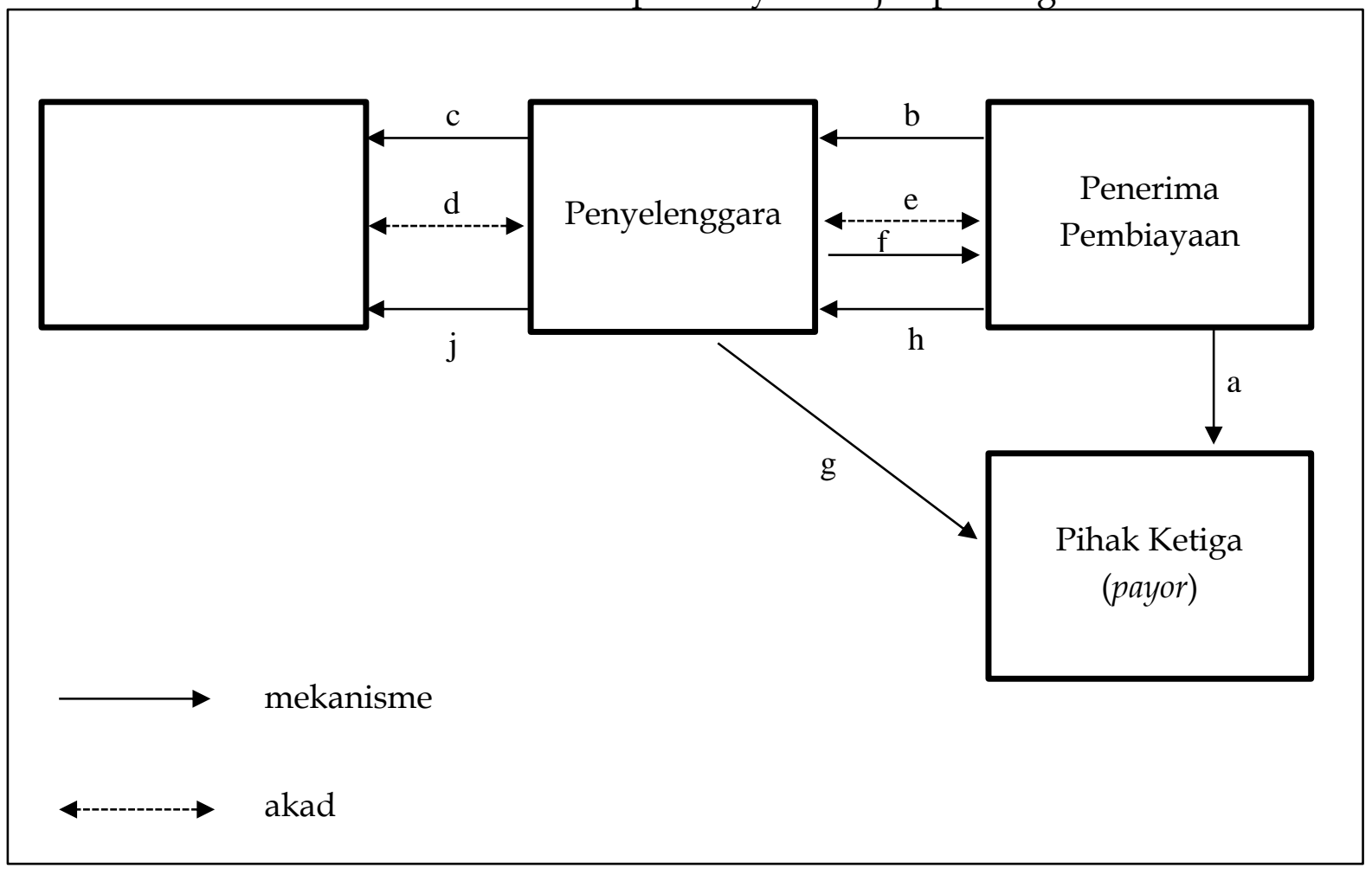

2) Pembiayaan pengadaan barang pesanan pihak ketiga (purchase order)

Model ini dilakukan dengan memberikan pembiayaan kepada pelaku usaha yang telah memperoleh pesanan atau surat perintah kerja pengadaan barang dari pihak ketiga.

Mekanismenya adalah:

a) Adanya akad yang menimbulkan hubungan pengadaan barang pesanan yang dibuktikan dengan kontrak pengadaan atara calon penerima pembiayaan dengan pihak ketiga yang menjadi dasar pembiayaan. 
b) Calon penerima pembiayaan mengajukan pembiayaan pengadaan barang kepada penyelenggara berdasarkan purchase order dari pihak ketiga.

c) Penyelenggara melakukan penawaran kepada calon pemberi pembiayaan untuk membiayai pengadaan barang tersebut.

d) Jika calon pemberi pembiayaan setuju maka dilakukan akad wakalah bi al-ujrah antara penyelengara dengan pemberi pembiayaan untuk melakukan akad pembiayaan. Pemberi pembiayaan sebagai muwakkil dan penyelenggara sebagai wakil.

e) Penyelenggara melakukan pembiayaan dengan penerima pembiayaan berdasarkan akad jual-beli (murabahah), musyarakah, atau mudharabah.

f) Penerima pembiayaan membayar pokok dan imbal hasil sesuai dengan kesepakatan dalam akad.

g) Penyelenggara wajib menyerahkan pokok dan imbal hasil kepada pemberi pembiayaan.

Gambar 3. Mekanisme model pembiayaan pengadaan barang pesanan kepada pihak ketiga

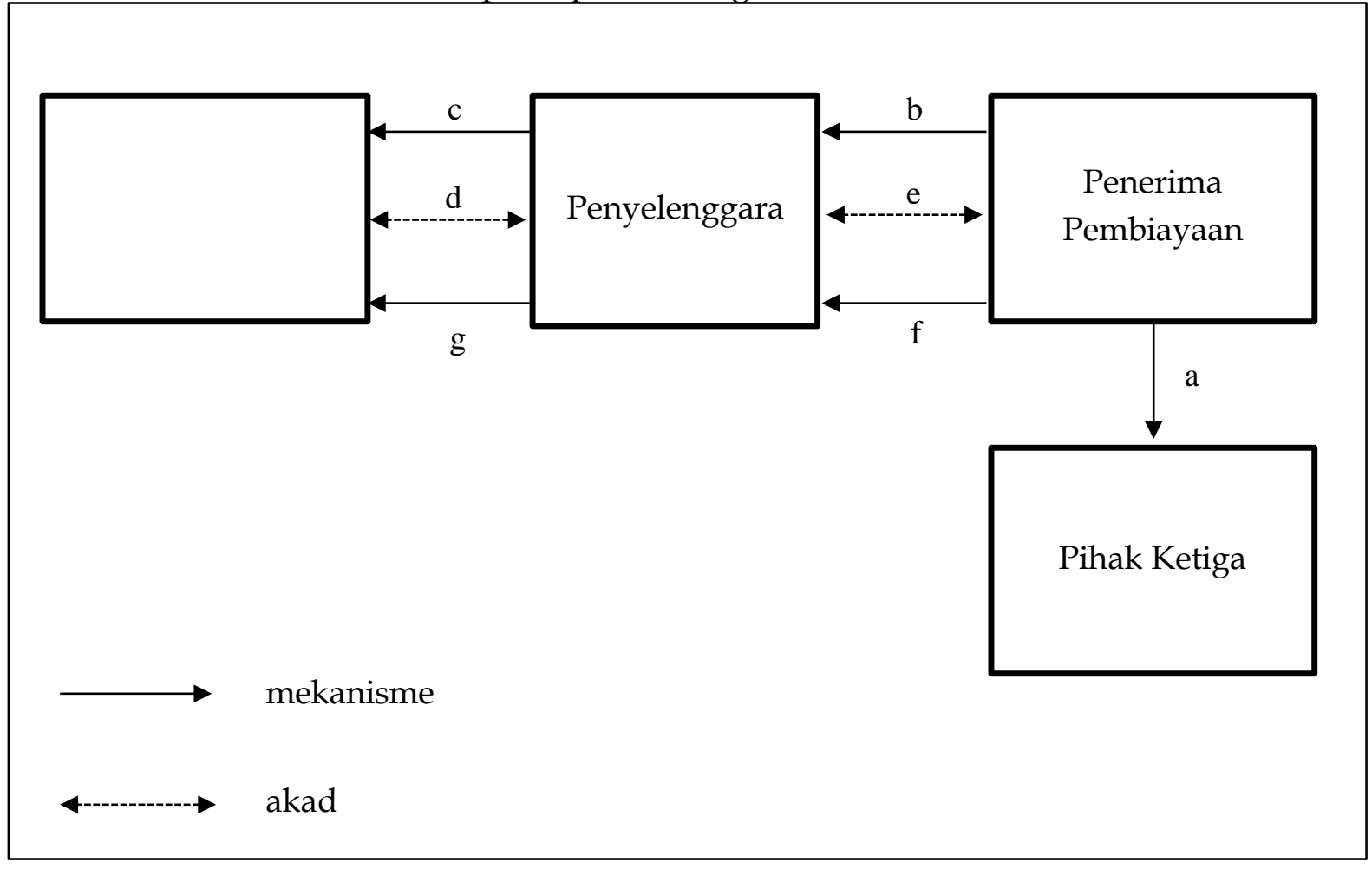




\section{3) Pembiayaan pengadaan barang untuk pelaku usaha yang} berjualan secara online (online seller)

Model pembiayaan ini memberikan layanan pembiayaan kepada pelaku usaha yang melakukan transaksi jual beli secara online pada penyedia layanan dagang berbasis teknologi informasi (platform ecommerce/marketplace) yang telah menjalin kerjasama dengan penyelenggara.

Mekanismenya adalah:

a) Penyediaan layanan perdagangan berbasis teknologi informasi (platform e-commerce/marketplace) dan penyelenggara melakukan kerjasama pemberian pembiayaan kepada pelaku usaha yang berjualan secara online (online seller) sebagai calon penerima pembiayaan.

b) Calon penerima pembiayaan mengajukan pembiayaan kepada penyelenggara untuk pengadaan barang.

c) Penyelenggara melakukan penawaran kepada calon pemberi pembiayaan untuk melakukan pembiayaan pengadaan barang.

d) Jika calon pemberi pembiayaan menyetujui, maka dilakukan akad wakalah bi al-ujrah antara penyelenggara dengan pemberi pembiayaan untuk melakukan akad pembiayaan dengan penerima pembiayaan. Pemberi pembiayaan sebagai muwakkil dan penyelenggara sebagai wakil.

e) Penyelenggara melakukan pembiayaan dengan penerima pembiayaan berdasarkan akad jual-beli (murabahah), musyarakah, atau mudharabah.

f) Penerima pembiayaan membayar pokok dan imbal hasil sesuai dengan kesepakatan dalam akad.

g) Penyelenggara wajib menyerahkan pokok dan imbal hasil kepada pemberi pembiayaan. 
Gambar 4. Mekanisme model pembiayaan pengadaan barang untuk pelaku usaha yang berjualan secara online (online seller)

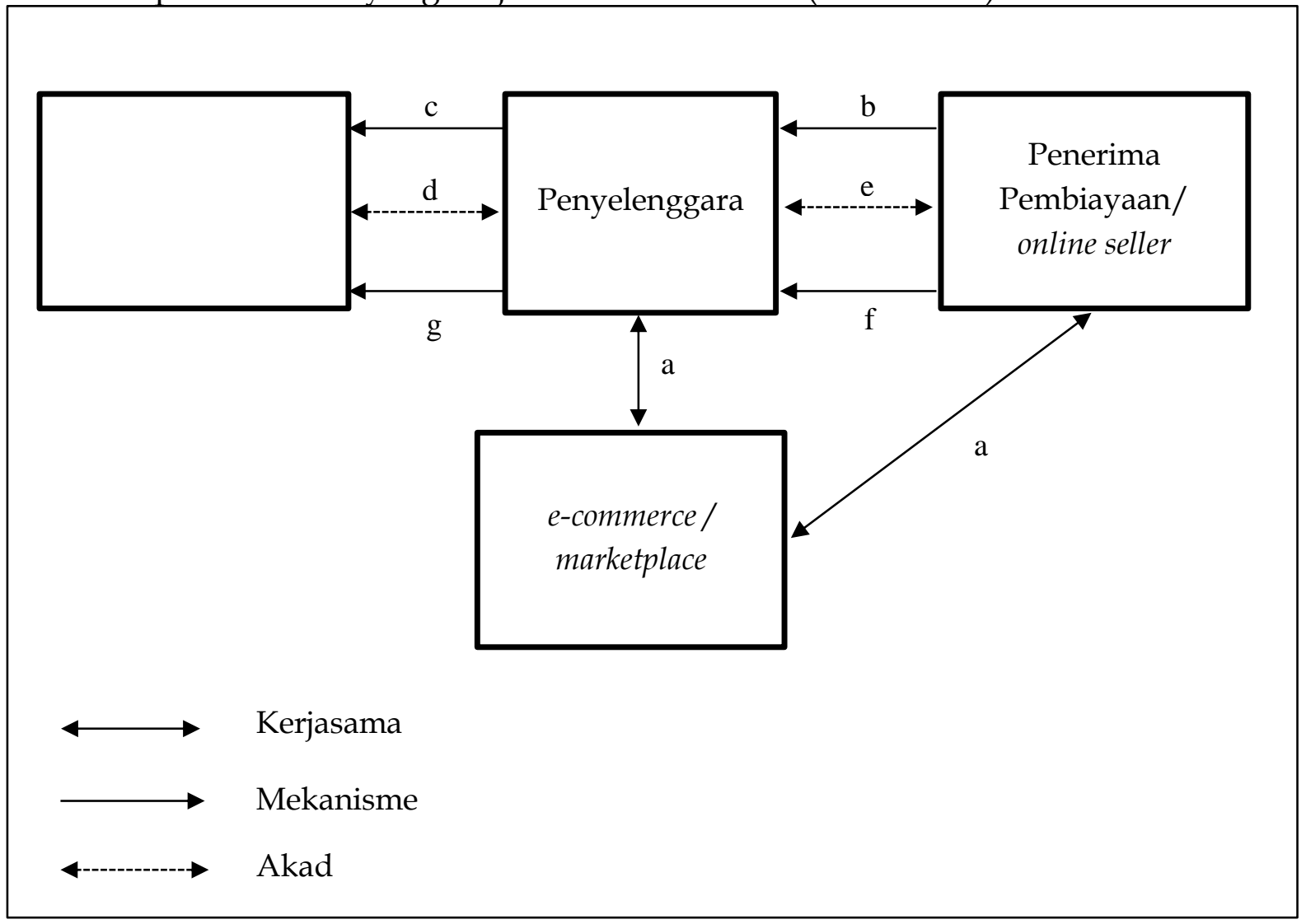

4) Pembiayaan pengadaan barang untuk pelaku usaha yang berjualan secara online dengan pembayaran melalui payment gateway

Model ini memberikan pembiayaan kepada pelaku usaha yang aktif berjualan secara online melalui saluran distribusi (channel distribution) yang dikelolanya sendiri dan pembayarannya dilakukan melalui penyedia jasa otoritas pembayaran secara online (payment gateway) yang bekerjasama dengan penyelenggara.

Mekanismenya adalah:

a) Penyedia jasa otorisasi pembayaran secara online (payment gateway) dan penyelenggara melakukan kerjasama pemberian pembiayaan kepada para penjual online (online seller) yang bekerjasama dengan penyedia jasa payment gateway.

b) Penjual online atau calon penerima pembiayaan mengajukan pembiayaan kepada penyelenggara untuk pengadaan barang. 
c) Penyelenggara melakukan penawaran kepada calon pemberi pembiayaan untuk membiayai pengadaan barang.

d) Jika calon pemberi pembiayaan menyetujui, dilakukan akad wakalah bi al-ujrah antara penyelenggara dengan pemberi pembiayaan untuk melakukan akad pembiayaan kepada penerima pembiayaan. Pemberi pembiayaan sebagai muwakkil dan penyelenggara sebagai wakil.

e) Penyelenggara sebagai wakil dari pemberi pembiayaan, memberikan pembiayaan kepada penerima pembiayaan dengan menggunakan akad jual-beli (murabahah), musyarakah, atau mudharabah.

f) Penerima pembiayaan membayar pokok dan imbal hasil melalui perusahaan penyedia jasa otorisasi pembayaran secara online (payment gateway) sesuai dengan kesepakatan dalam akad.

g) Penyelenggara wajib menyerahkan pokok dan imbal hasil kepada pemberi pembiayaan.

Gambar 5. Mekanisme model pembiayaan pengadaan barang untuk pelaku usaha yang berjualan secara online (online seller) dengan pembayaran melalui payment gateway

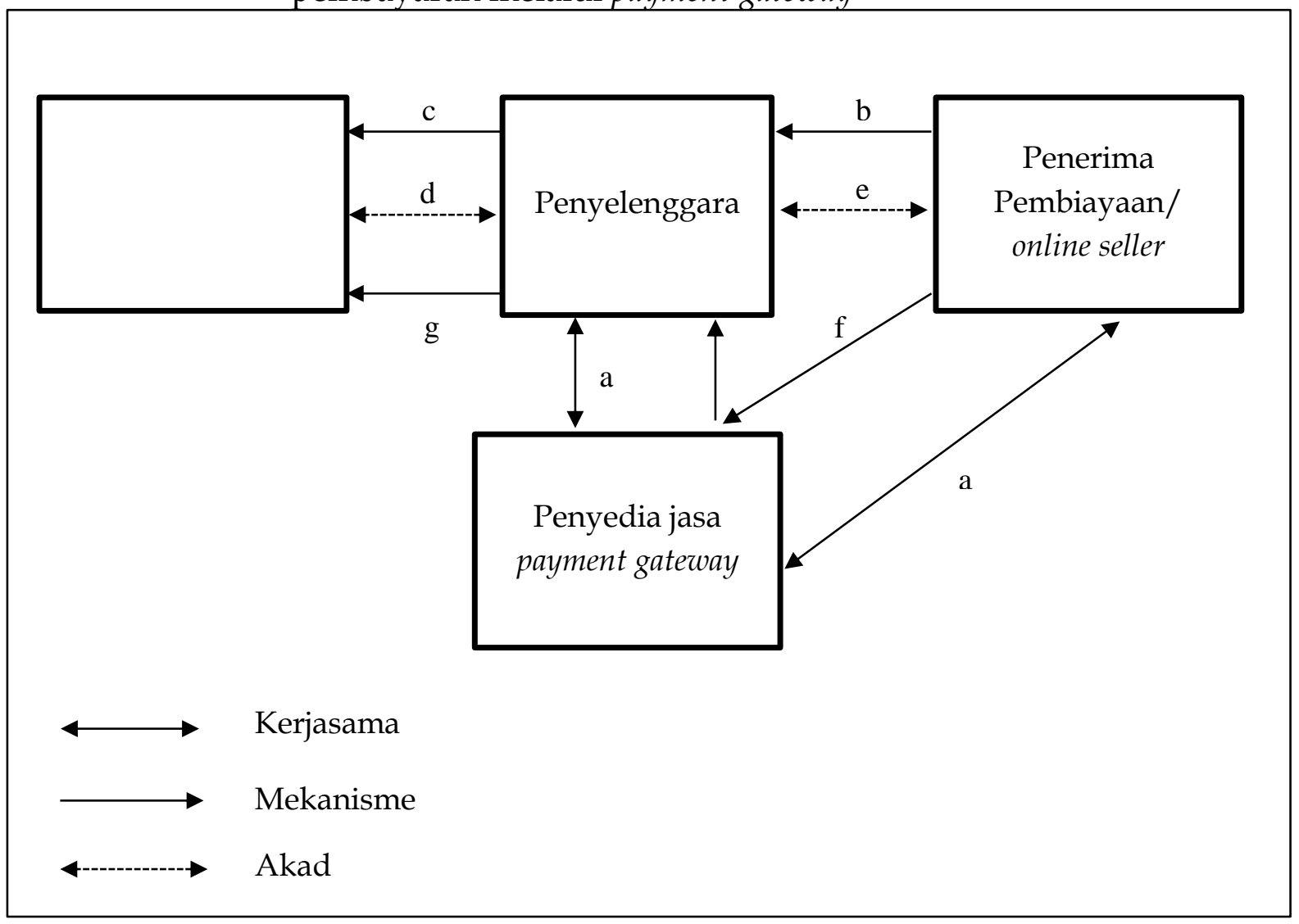




\section{5) Pembiayaan untuk pegawai}

Model ini memberikan pelayanan pembiayaan kepada pegawai yang membutuhkan pembiayaan konsumtif dengan skema kerja sama potong gaji melalui instansi pemberi kerja.

Mekanismenya adalah:

a) Adanya pegawai yang mendapatkan gaji tetap dari institusi yang bekerjasama dengan penyelenggara.

b) Pegawai / calon penerima pembiayaan yang memiliki kebutuhan konsumtif mengajukan pembiayaan kepada penyelenggara.

c) Penyelenggara menawarkan kepada calon pemberi pembiayaan untuk membiayai kebutuhan konsumtif calon penerima pembiayaan.

d) Jika calon pemberi pembiayaan menyetujui, dilakukan akad wakalah bi al-ujrah antara pemberi pembiayaan dengan penyelenggara untuk melakukan pembiayaan dengan penerima pembiayaan. Pemberi pembiayaan sebagai muwakkil dan penyelenggara sebagai wakil.

e) Penyelenggara sebagai wakil dari pemberi pembiayaan melakukan akad jual-beli (murabahah) atau ijarah dengan penerima pembiayaan sesuai kesepakatan.

f) Penerima pembiayaan membayar pokok dan imbal hasil kepada penyelenggara dengan cara pemotongan gaji / auto debet rekening.

g) Penyelenggara wajib menyerahkan pokok dan imbal hasil kepada pemberi pembiayaan. 
Gambar 6. Mekanisme model pembiayaan untuk pegawai

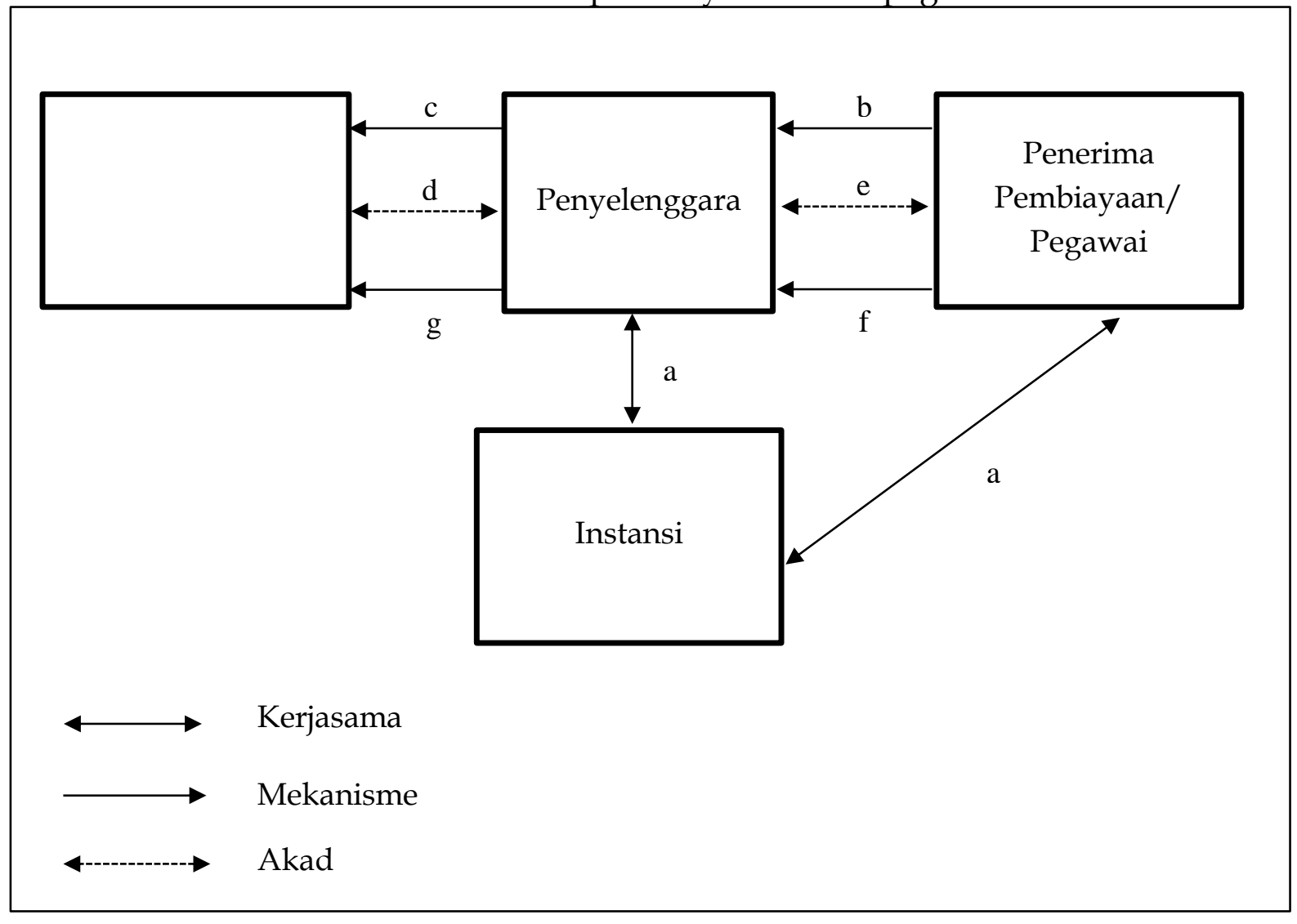

\section{6) Pembiayaan berbasis komunitas (community based)}

Penyelenggara juga menyediakan layanan pembiayaan yang diberikan kepada anggota komunitas yang membutuhkan pembiayaan dengan skema pelunasan dikoordinasikan dengan pengurus komunitas. Mekanismenya adalah:

a) Adanya pelaku usaha yang tergabung dalam komunitas usaha tertentu yang bekerja sama dengan penyelenggara.

b) Pelaku usaha/calon penerima pembiayaan yang membutuhkan modal mengajukan kepada penyelenggara.

c) Penyelenggara mengajukan penawaran kepada calon pemberi pembiayaan untuk memberikan modal kepada calon penerima modal.

d) Jika calon pemberi pembiayaan menyetujui, maka dilakukan akad wakalah bi al-ujrah antara pemberi pembiayaan dengan penyelenggara untuk memberikan pembiayaan kepada penerima pembiayaan. Pemberi pembiayaan sebagai muwakkil dan penyelenggara sebagai wakil.

e) Penyelenggara sebagai wakil pemberi pembiayaan melakukan akad dengan penerima pembiayaan dengan akad jual-beli (murabahah), 
ijarah, musyarakah, mudharabah atau akad lain yang sesuai dengan prinsip Syariah.

f) Penerima pembiayaan membayar pokok dan imbal hasil kepada penyelenggara melalui komunitas usaha tertentu yang bekerja sama dengan penyelenggara.

g) Penyelenggara wajib menyerahkan pokok dan imbal hasil kepada pemberi pembiayaan.

Gambar 7. Mekanisme model pembiayaan berbasis komunitas (community based)

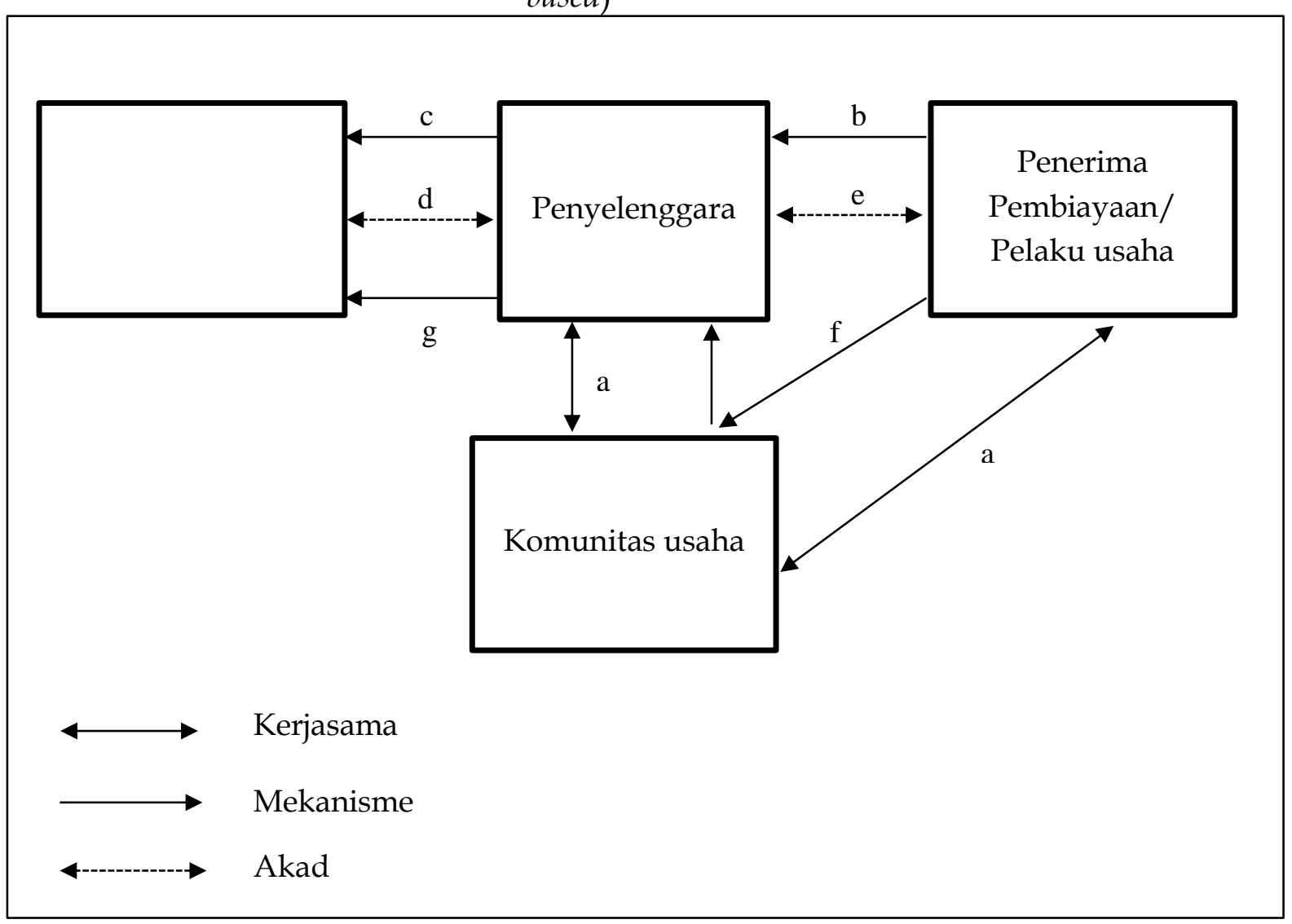




\section{KESIMPULAN}

Fintech peer-to-peer lending berbasis Syariah merupakan penyelenggaraan layanan jasa keuangan berdasarkan prinsip Syariah yang mempertemukan atau menghubungkan pemberi pembiayaan dengan penerima pembiayaan dalam rangka melakukan akad pembiayaan melalui sistem elektronik dengan menggunakan jaringan internet. Subyek hukum Fintech peer-to-peer lending ada tiga pihak, yaitu penyelenggara, pemberi pembiayaan, dan penerima pembiayaan. Fintech peer-to-peer lending berdasarkan prinsip Syariah menurut Fatwa DSN-MUI dapat dilakukan dengan model: 1) pembiayaan anjak piutang, 2) pembiayaan pengadaan barang pesanan pihak ketiga, 3) pembiayaan pengadaan barang untuk pelaku usaha yang berjualan secara online, 4) pembiayaan pengadaan barang untuk pelaku usaha yang berjualan secara online dengan pembayaran melalui payment gateway, 5) pembiayaan untuk pegawai, 6) pembiayaan berbasis komunitas. Mekanismenya adalah terdapat dua akad terpisah dalam setiap model, yaitu antara penyelenggara dengan pemberi pembiayaan dan antara penyelenggara dengan penerima pembiayaan. Penyelenggara dengan pemberi pembiayaan menggunakan akad wakalah bi al-ujrah, sedangkan antara penyelenggara dengan penerima pembiayaan bisa menggunakan akad wakalah bi al-ujrah, murabahah, mudharabah, musyarakah, ijarah, atau qardh sesuai dengan model yang digunakan.

\section{DAFTAR PUSTAKA}

Au, Y. A., \& Kauffman, R. J. (2008). The economics of mobile payments: Understanding stakeholder issues for an emerging financial technology application. Electronic Commerce Research and Applications, 7(2), 141-164. https:/ / doi.org/10.1016/j.elerap.2006.12.004

Bank Indonesia. (2017). Peraturan Bank Indonesia Nomor 19/12/PBI/2017 tentang penyelenggaraan teknologi finansial

Cai, S., Lin, X., Xu, D., \& Fu, X. (2016). Judging online peer-to-peer lending behavior: A comparison of first-time and repeated borrowing requests. Information and Management, 53(7), 857-867. https:/ / doi.org/10.1016/j.im.2016.07.006

Creswell, J. W. (2010). Research Design. Yoogyakarta: Pustaka Pelajar.

Davis, F. D. (1989). Perceived Usefulness, Perceived Ease of Use, and User Acceptance of Information Technology. MIS Quarterly, 13(3), 319-340. https:/ / doi.org/10.2307/249008

DSN-MUI. (2008). Fatwa DSN-MUI Nomor 67/DSN-MUI/III/2008 tentang Anjak Piutang Syariah. 
DSN-MUI. (2018). Fatwa DSN-MUI Nomor 117/DSN-MUI/II/2018 tentang Layanan Pembiayaan Berbasis Teknologi Informasi Berdasarkan Prinsip Syariah.

Koperasi, S. K., \& Ukm, D. (2017). ARAH KEBIJAKAN BIDANG KOPERASI DAN USAHA MIKRO, KECIL DAN MENENGAH Ir. Agus Muharram, MSP ARAH KEBIJAKAN BIDANG KOPERASI DAN USAHA MIKRO, KECIL DAN MENENGAH.

OJK. (2015). Roadmap IKNB Syariah 2015-2019.

OJK. (2016). Peraturan OJK Nomor 77/POJK.01/2016 tentang Layanan Pinjam Meminjam Uang Berbasis Teknologi Informasi.

OJK. (2018). Direktori Fintech per Juni 2018. Jakarta. Retrieved from https:/ / www.ojk.go.id/id/kanal/iknb/data-danstatistik/direktori/fintech/Default.aspx

Yum, H., Lee, B., \& Chae, M. (2012). Electronic Commerce Research and Applications From the wisdom of crowds to my own judgment in microfinance through online peer-to-peer lending platforms. Electronic Commerce Research and Applications, 11(5), 469-483. https:/ / doi.org/10.1016/j.elerap.2012.05.003 